\title{
MONITORING OF TRANSPORT COMMUNICATIONS
}

\author{
Matsiy M. E. ${ }^{1}$, Aleksiyev O. P. ${ }^{1}$ \\ ${ }^{1}$ Kharkov National Automobile and Highway University
}

\begin{abstract}
Problem. Monitoring of transport communications is a new definition of a complex of works on the analysis of the status and reliability of individual units and the corresponding motor transport communication in general. The content of interactive monitoring is to monitor records continuously, accumulate and summarize data on the operational situation in the traffic environment. In connection with the constant information of society development and its industrial component, new transport systems and machines have reached a high level of information excellence. Accordingly, there is a new contradiction between the rapid development of means and methods of informatization of complex objects and systems and the heterogeneous nature of existing subsystems and units of the transport complex of Ukraine, which is also characteristic of the market of transport services. Methodology. The assessment and diagnosis of highways is based on their observation. A generalized means of such observation is their monitoring. It is he who provides not only monitoring of the condition of highways, but also the preparation of data for solving tasks of assigning tasks to road-operation services, road and transport enterprises and organizations. Results. The problem of solving this contradiction will allow to improve the service of the inhabitants of cities and regions at all levels of the transport infrastructure, to improve the transportation processes, to avoid the existing negative influences: crashes in the organization of traffic, poor state of communication, inappropriate use of funds allocated for repair, operation and arrangement of transport highways. The goal of monitoring (diagnostics and transport systems assessment) lies in obtaining full and adequate information about functional quality of transport communications, their work conditions and degree of actual consumer appeal conformity to vehicular traffic requirements. Practical value. The diagnostic results are basic for transport communications condition management and they are the original basis for efficient usage of means aimed at road network improvement and development.
\end{abstract}

Key words: computer systems; interactive monitoring; navigation; transport communication.

\section{Introduction}

Interactive monitoring is an instrumental tool for monitoring the state of roads. The difference in monitoring from the usual supervision is to determine the background history of the operational state of roads. The content of interactive monitoring is monitor records constantly, accumulate and summarize data on the operational situation in the traffic environment.

\section{Publication analysis}

Plenty of authors in Ukraine and abroad pay attention to the monitoring of transport communications in their papers [2-4].

\section{The objective and problem statement}

Interactive monitoring of the state of the highway is based on the combination of three components of its physical implementation. First, they register speed and acceleration of the car using an external system determining its location in space in accordance with time, and secondly, continuous video recording using a video camera (WEB camera) and a digital camera is carried out. The third component of the system is direct assessment and presentation of road conditions by road users (for example, recording comments of the operator of a road machine, an experienced expert of the truck, who takes part in the maintenance of the relevant road section).

Such observation is not just an organizational and technical system, but an interactive system where the main activity of automotive monitoring roads involves a person. It involves the use of expert experience, marking the appropriate environment of the road and in the road.

Thus, we have a synergistic system that combines technical and ergonomic components

At present, there are mathematical methods that allow to be combined subjectivity with exact technical calculation. This is so-called fuzzy approach or pacifications, which is a process of comparing the understanding of human and quantitative technical assessments.

The first step is to use the fuzzy-approach for simulation of complex transport objects and systems is the task of phase-out, a formal description of the observed dynamic motion processes. 
Fuzzy logics today is widely represented in fundamental and applied scientific publications.

Bringing the description of the studied system to a fuzzy look begins with the definition of linguistic variables, their meanings - terms, conducting an analogy between quantitative estimates of subsystems and parts of the system and their fuzzy description.

This task is close to the definition of distinction observable dynamic processes in accordance with the basic provisions of the informational theory of management, presenting the observation as the result of the analysis of the system under study: the normalization of data, their structural and pragmatic processing. Then the observation as monitoring of the road can be defined

According to the assumptions made, fuzzy description or pacification examines the processes and systems we consider from the standpoint of the main provisions: the information theory of distinction [1], the basics of making decisions in complex monitoring systems for road vehicles, transport systems and communications

Needs of cities and regions inhabitants, manufacturing organizations in passenger and cargo transportation depend on the constant transport infrastructure: means of communication, transport machines and technologies and lots of other subsystems and sections of the transport complex, which render services to people and organizations.

It should be mentioned, that nowadays the situation with highway transportation can be described by advance development of automobile park, accordingly higher mobility of cities and regions inhabitants and limited transport network capabilities.

Transport communication are becoming a narrow branch of the transport network of cities and regions. They demand continuous attention to all existing stages- starting from scientific substantiation, engineering and research work, to construction and maintaining.

It goes without saying, that their working conditions need constant inspection. Its results is a basis for decision-making on issues like material, financial and human resources, transport communication maintenance, exploitation, repairs and reengineering.

There is a specific system in transport that provides control and preliminary treatment of transport communication conditions. Their quality is generally evaluated with the help of instruments, appliances, devices and systems. In the world practice of assessing and diagnosing transport communications conditions, powerful information-measuring system with a high automation level of transport communications inspection have been developed. In Ukraine the function of transport communication condition assessment is performed by the technical research center.

To determine requirements for transport communication interactive monitoring, we will make use of experience of computer systems creation designed for transport communications monitoring [2].

On this basis we will work up a new modification of an engineering prototype of transport and communication computation process, to be used for driving conditions monitoring directly during the vehicle movement. This device enables to determine road characteristics according to patents [2].

In the researches some information is given in order to clarify how the transport communications monitoring is conducted with the help of this system.

The previously obtained certificate $[3,4]$ confirms the legitimacy of using these characteristics of transport and methods of road topping condition observation, as meteorological characteristics.

The results of diagnostics and assessment of road condition must become a solid information base for solving managing tasks of two levels:

1. Determination and assessment of engineering level, condition with respect to use for traffic, degree of conformity of an actual consumer appeal to parameters and characteristics of traffic safety measures;

2. Making managerial decisions regarding determination of high priority measures in order to improve certain transport communication sectors on the ground of rational usage of financial resources and facilities.

Transport communication monitoring is a new definition of range of activities that consists of analyzing the condition and robustness of special parts and corresponding motor transport communication largely.

Transport communication condition is usually determined as a total of its transport-operational characteristics.

Transport communication reliability is an ability to provide safe defined motion at average speed, near to the best possible one. According to [4] optimization is understood to be minimization of total expenditures for construction, transport communication operation activity, passenger and cargo transportation.

The essence of monitoring lies in transport 
communication characteristics observation, which can be selective or continuous. Speaking of transport communications operation activity system, there is no doubt that monitoring has to be unceasing in space and time. But this has to be done with high expenses for conducting of complete transport communication examination $[2,3$, 4].

Appropriate transport communication assessment in based on model approximation model, which enables to choose primary parameters, characteristics of objects examined, to determine their list, to estimate their significance and high priority of calculation and accounting.

Obviously it is a task of their connection analysis, analytical recalculation possibilities, specific values origination of indirect, calculated and generalized assessments, which make it possible to take management decisions. Doubtlessly such analysis must be performed not on the generalized level, but immediately on the assessment of a transport communications certain sector condition in accordance with ILM of transport communications, as stated above.

For this reason, there is a number of analytical, graphical and some heuristic methods. However, the diagnostic practice of different road situations proves that the most significant is the statement that speed, geometry, smoothness and adhesion (adhesion coefficient) assessments are the most necessary.

Today the problem is to raise road travelers awareness of transport communication condition. There is a contradiction between the level of modern accounting systems, necessity to obtain them, dynamic accumulation and constant character of current electronic data base maintenance ways in the road sector.

The resolution of this conflict lies in creating alongside with the existing quality assessment system of road production a multilayer complex of transport communications condition monitoring that is based on designing road tester sequence - a source of information about transport communications elements condition, data transmission medium to a single information space of road organizations.

In the work the analytical review of the transport communications condition assessment problem under conditions of information-communicative technology of above-ground transport has been conducted. The programmersimulator of a road accidents monitor was designed through the example of road geometry assessment.

The composed algorithm corresponds to logics of a human understanding of vehicle movement monitoring. The essence of monitoring (diagnostics and transport systems assessment) lies in obtaining full and adequate information about functional quality of transport communications, their work conditions and degree of actual consumer appeal conformity to vehicular traffic requirements.

\section{Conclusion}

The diagnostic results are basic for transport communications condition management and they are the original basis for efficient usage of means aimed at road network improvement and development.

\section{Література}

1. Алексієв О. П., Алексієв В. О., Видмиш А. А., Хабаров О. О. Інтерактивний моніторинг автомобільних доріг: монографія. ВНТУ. Вінниця. 2012. C. 144.

2. Алексієв О. П., Алексієв В. О., Сєріков С. А. Підвищення ефективності диспетчерського управління громадським пасажирським транспортом. Вестник ХНАДУ. Сб. науч. тр. Харьков. Вып. 22. 2003. С. 56-61.

3. Алексієв О. П., Алексієв В. О., Ніконов О. Я. Мехатроніка, телематика, синергетика у транспортних додатках. навчально-методичний посібник. ХНАДУ. Харків. 2011. С. 212.

4. Shamieh C. System Engineering for Dummies. Wiley Publishing. Inc. Indianapolis. Indiana. 2011. $74 \mathrm{p}$.

\section{References}

1. Aleksiyov O. P., Aleksiyev V. O., Vidmish A. A., Khabarov O. O. (2012) Interactivmiy monitoring automobilnih dorog [Interactive monitoring of automobile roads]. Vinnitsa, 144 [in Ukraine].

2. Aleksiv O. P., Aleksiv V. O., Sirikov S. A. (2003) Pidvishchennya performance of the dispatching control of the passenger transport [Improving the efficiency of public passenger transport dispatch control]. Kharkov, 22, 56-61 [in Ukraine].

3. Aleksiyev O. P., Aleksiyev V. O, Nikonov O. Ya. (2012) Mechatronica, telematica, synergetica $\mathrm{V}$ transportnih dodatkah [Mechatronics, telematics, synergetics in transport applications]. Kharkiv, 212 [in Ukraine].

4. Shamieh System C. (2011) Engineering for Dummies. Wiley Publishing. Inc. Indianapolis. Indiana, 74

Matsiy My`xajlo ${ }^{1}$, graduate student $\underline{\mathrm{mi}-}$ chael.matsiy@gmail.com.

Aleksiyev Oleg${ }^{1}$, professor, dr. eng. sc., o.p.alekseev@gmail.com.

${ }^{1}$ Kharkov National Automobile and Highway University, 25, Yaroslav Mudry street, Kharkiv, 61002, Ukraine. 
Моніторинг транспортних комунікацій

Анотація: Проблема. Моніторинг транспортних комунікацій - це нове визначення комплексу робіт з аналізу стану та надійності окремих вузлів та відповідного автотранспортного зв'язку в циілому. Зміст інтерактивного моніторингу - постійне спостереження за записами, накопичення та узагальнення даних про операційну ситуацію 6 середовищі дорожнього руху. $У$ зв'язку 3 постійною інформацією про розвиток суспільства та ¥ї промислової складової, нові транспортні системи та машини досягли високого інформаційного рівня інформаційної. Існує протиріччя між швидким розвитком засобів та методів інформатизації складних об'єктів та систем та різнорідністю існуючих підсистем та підрозділів транспортного комплексу України, щзо характерно для ринку транспортних послуг. Методологія. Оцінка $і$ діагностика автомобільних доріг заснована на $\ddot{x}$ спостереженні. Узагальненим засобом такого спостереження $\epsilon$ ї моніторинг. Саме він забезпечує не тільки моніторинг стану автомобільних доріг, а й підготовку даних для вирішення задач з постановки завдань дорожньоексплуатаційним службам, дорожньотранспортним підприємствам $і$ організачіям. Результати. Проблема вирімення цієї суперечності дозволить поліпшити обслуговування жителів міст і районів на всіх рівнях транспортної інфраструктури, поліпшити транспортні прочеси, уникнути існуючих негативних впливів: збоїв в організації дорожнього руху, поганий стан зв'язок, нецільове використання коштів, виділених на ремонт, експлуатацію та облаштування транспортних магістралей. Метою моніторингу (діагностики та оитінки транспортних систем) є отримання повної та адекватної інформації про функиіональну якість транспортних комунікацій, їх умови роботи та ступінь фактичної відповідності споживачів вимогам щуодо руху транспорту. Практична цінність. Результати діагностики є базовими для управління станом транспортних комунікацій $i$ є вихідною основою для ефективного використання коштів, спрямованих на поліпшення та розвиток дорожньої мережі.

Ключові слова: комп'ютерні системи; інтерактивний моніторинг; навігація; транспортна комунікація.

Маций Михайло Свгенійович ${ }^{\mathbf{1}}$, аспірант каф. KTM, michael.matsiy@gmail.com

Алексісв Олег Павлович ${ }^{1}$, д.т.н., професор каф. KTM, e-mail: o.p.alekseev@gmail.com.

${ }^{1}$ Харківский національний автомобільнодорожній університет, Україна, Харків, 61002, вул. Ярослава Мудрого, 25.

\section{Мониторинг транспортных коммуникаций}

Аннотация: Мониторинг транспортных коммуникаичй - это новое определение комплекса работ по анализу состояния и надежности отдельных звеньев и соответствующей автотранспортной коммуникации в целом. Содержание интерактивного мониторинга заключается в постоянном наблюдении, регистрации, накопления и обобщения данных об оперативной ситуащии в среде дорожного движения.

Ключевые слова: компьютерные системы; интерактивный мониторинг; навигация; транспортная коммуникация.

Маций Михаил Евгениевич', аспирант каф. KTM, michael.matsiy@gmail.com.

Алексеев Олег Павлович ${ }^{1}$, д.т.н., профессор каф. KTM, e-mail: o.p.alekseev@gmail.com.

${ }^{1}$ Харьковский национальный автомобильнодорожный университет, Украина, Харьков, 61002, ул. Ярослава Мудрого, 25. 